\title{
PENGARUH FAKTOR DEMOGRAFI TERHADAP QUALITY OF NURSING WORK LIFE (QNWL) PERAWAT RUMAH SAKIT MUHAMMADIYAH BANDUNG
}

\author{
Asih Purwandari W. P. ${ }^{1}$, F Sri Susilaningsih ${ }^{2}$, Irman Somantri ${ }^{3}$ \\ ${ }^{1}$ Prodi DIII Keperawatan FPOK Universitas Pendidikan Indonesia \\ ${ }^{2,3}$ Fakultas Keperawatan Universitas Padjadjaran \\ Email: 1asihpurwandari@upi.edu
}

\begin{abstract}
ABSTRAK
Perawat sebagai SDM dengan jumlah terbanyak di rumah sakit,mempunyai peranan penting dalam pencapaian tujuan dan kualitas rumah sakit. Untuk bisa mencapai tujuan rumah sakit memerlukan perawat yang memiliki komitmen organisasi dan kinerja yang baik, Quality of Nursing Work Life (QNWL) adalah salah satu faktor penting yang mempengaruhi komitmen dan kinerja perawat. Permasalahan perawat di Rumah Sakit Muhammadiyah Bandung (RSMB) terindikasi memiliki Quality of Nursing Work Life (QNWL) kurang baik yang berdampak pada kurang baiknya komitmen dan kinerja perawat. Oleh karena itu, diperlukan penelitian lebih lanjut terkait QNWL perawat RSMB. Penelitian ini bertujuan untuk mengetahui gambaran QNWL perawat RSMB, mengetahui gambaran demografi beserta pengaruhnya terhadap QNWL perawat RSMB Penelitian deskriptif cross- sectional survey ini, melibatkan 94 perawat yang diambil dengan cara kuantitatif. Data dikumpulkan dengan kuesioner, dan dianalisis menggunakan uji non-parametrik Mann Whitney. Penelitian ini dilakukan pada akhir bulan Januari 2017 di Rumah Sakit Muhammadiyah Bandung. 'Hasil penelitian ini menunjukkan bahwa perawat di RSMB memiliki nilai QNWL secara keseluruhan dan dimensi-dimensi QNWL yang berada dalam kategori baik. Hasil penelitian ini juga menunjukkan bahwa tiga faktor demografi berpengaruh signifikan terhadap QNWL perawat, yaitu: faktor jenis kelamin $(p=0.04)$, umur $(p=0.006)$ dan lama bekerja sebagai perawat $(p=0.009)$. Sedangkan, dari segi status pernikahan $(p=0.71)$, tingkat pendidikan $(p=0.71)$ dan lama bekerja sebagai perawat di $\operatorname{RSMB}(p=0.173)$ tidak berpengaruh signifikan. Implikasi penelitian ini adalah perlu adanya upaya perbaikan komponenkomponen dan faktor-faktor QNWL yang masih bermasalah. Kunci utama terletak pada upaya penerapan sistem penilaian kinerja perawat yang dihubungkan dengan jenjang karir perawat dan sistem penggajian perawat.
\end{abstract}

Kata kunci: Quality Of Nursing Work Life (QNWL), Kualitas Kehidupan Kerja Perawat, Faktor-Faktor Demografi Quality Of Nursing Work Life (QNWL)

\section{ABSTRACT}

Nurses as the highest number of human resources in hospital have an important role in achieving the goals and qualities of hospital. In order to achieve the goals, hospitals require nurses who are committed to the organization and have a good performance. Quality of Nursing Work Life (QNWL) is one of the important factors which affect the nurses' organizations' commitment and performance. The problem of nurses at Muhammadiyah Hospital Bandung (RSMB) can be identified from the low number of nurses' QNWL which affect the nurses' commitment and performance. Therefore, further researches related to QNWL in RSMB nurses are needed. This study aimed to investigate the nurses 'QNWL in $R S M B$, discover demographic factors and its influence on nurses' QNWL in RSMB. This descriptive cross-sectional survey was conducted on 94 nurses taken by a quantitative manner. The Data were collected through questionnaire and analyzed using non-parametric test of Mann Whitney. This research was conducted at the end of January 2017 at Muhammadiyah Hospital Bandung.

The results of this research showed that nurses at Muhammadiyah Hospital Bandung overall have a good level of Quality of Nursing Work Life (QNWL) in each dimensions. The results also showed that 
three demographic factors significantly influence QNWL of nurses, which are gender ( $p=0: 04)$, age ( $p$ $=0.006)$ and length of work as a nurse $(p=0.009)$. Meanwhile, there is no significant relationship in terms of marital status $(p=0.71)$, educational level $(p=0.71)$ and length of work as nurses in RSMB $(p=0.173)$. The implication of this research is the need to improve the problematic components dan factors of QNWL. The main key lies in promoting the evaluation performance system linked to the nurses' career development opportunities and nurses' salary.

Keywords: Quality of Nursing Work Life (QNWL), demographic factor of Quality Nursing Work Life $(Q N W L)$

\section{PENDAHULUAN}

Perkembangan ilmu pengetahuan dan teknologi telah membawa perubahan hampir disemua aspek kehidupan manusia termasuk dalam bidang pelayanan kesehatan, salah satunya rumah sakit. Selain bermanfaat bagi kehidupan manusia di satu sisi perubahan tersebut juga telah membawa manusia ke era persaingan global yang semakin ketat. Agar mampu berperan dalam persaingan global, maka rumah sakit perlu terus mengembangkan dan meningkatkan kualitas sumber daya yang dimiliki olehnya.

Undang-Undang Republik Indonesia No. 44 tahun 2009 tentang rumah sakit, menyatakan bahwa rumah sakit adalah institusi pelayanan kesehatan yang menyelenggarakan pelayanan kesehatan perorangan secara paripurna yang menyediakan pelayanan rawat inap, rawat jalan dan gawat darurat. Rumah sakit adalah subsistem dari sistem yang lebih besar yaitu sistem pelayanan kesehatan yang tidak lain adalah subsistem dari sistem kesehatan nasional (Soeroso, 2003).

Rumah sakit memiliki berbagai macam sumber daya sebagai penunjang aktivitas operasionalnya, seperti Sumber Daya Manusia (SDM), modal, peralatan dan perlengkapan, fasilitas infrastruktur, dan lain sebagainya. Dari beberapa sumber daya yang dimiliki rumah sakit, Salah satu SDM yang paling besar serta mempunyai peranan paling penting dalam pencapaian tujuan rumah sakit dan kualitas rumah sakit adalah perawat. Keberhasilan pelayanan rumah sakit sangat bergantung pada partisipasi perawat dalam memberikan perawatan yang berkualitas bagi klien (Potter \& Perry, 2005). Hal ini terkait dengan keberadaan perawat yang bertugas selama 24 jam melayani pasien dan jumlah perawat yang mendominasi tenaga kesehatan di rumah sakit, yaitu sekitar $40-60 \%$ (Swansburg, 2000; PPNI, 2005). Tanpa SDM perawat yang memadai, pelayanan di rumah sakit tidak akan berjalan dengan baik.

Perawat adalah seseorang yang telah menyelesaikan program pendidikan keperawatan, berwenang di negara bersangkutan untuk memberikan pelayanan dan bertanggung jawab dalam peningkatan kesehatan, pencegahan penyakit serta pelayanaan terhadap pasien (International Council of Nursing, 1965). Menurut UU kesehatan No.23 tahun 1992 tentang kesehatan, perawat adalah mereka yang mempunyai kemampuan dan kewenangan melakukan tindakan keperawatan berdasarkan ilmu yang dimilikinya yang diperoleh melalui pendidikan keperawatan. Untuk bisa mencapai tujuan, rumah sakit memerlukan perawat yang memiliki komitmen organisasi dan kinerja yang baik.

Menurut Meyer dan Allen (1991) dalam Soekidjan (2009), Komitmen organisasi adalah penerimaan yang kuat individu terhadap tujuan dan nilai-nilai organisasi, serta individu berupaya serta berkarya dan memiliki hasrat yang kuat untuk tetap bertahan di organisasi tersebut. Salah satu rumah sakit yang mengalami masalah komitmen SDM perawat adalah Rumah Sakit 
Muhammadiyah Bandung. Hal ini salah satunya ter-indikasi dari angka turnover perawatnya yang tinggi. Berdasarkan data SDM RS Muhammadiyah Bandung, bahwa Tahun 2014 tercatat 15 orang perawat yang mengundurkan diri dari 220 perawat atau 6,82 \%. Lalu pada Tahun 2015 tercatat 6 orang perawat yang mengundurkan diri dari 233 perawat atau 2,57\%. Dan pada Tahun 2016 tercatat 8 orang perawat yang mengundurkan diri dari 227 perawat atau 3,52\%.

Berdasarkan hasil laporan SDM terkait kehadiran perawat RS Muhammadiyah Bandung periode Januari 2015 sampai dengan Oktober 2016 (22 Bulan) menunjukkan ratarata perawat yang terlambat adalah 8 orang $(4,55 \%)$ perhari dari 171 orang perawat dan rata-rata perawat yang pulang sebelum waktunya adalah $2-3$ orang $(1,44 \%)$ perhari dari 171 orang perawat. Kebijakan penerapan absensi finger print yang dihubungkan dengan kebijakan pemotongan insentif terlihat belum cukup efektif. Para perawat mengungkapkan pemotongan insentif tidak terlalu besar jumlahnya dan tidak terlalu signifikan mempengaruhi pendapatan mereka.

Kinerja adalah penampilan hasil karya personel baik kualitas maupunkuantitas dalam suatu organisasi.Kinerja dapat merupakan penampilan individu maupun kelompok kerja personel. Penampilan hasil karya tidak terbatas pada personel yang memangku jabatan fungsional maupun struktural, tetapi juga kepada seluruh jajaran personel di dalam organisasi (Ilyas, 2002). Terdapat juga pendapat lain seperti yang dikemukakan oleh Mangkunegara (2006), bahwa kinerja karyawan (prestasi kerja) adalah hasil kerja secara kualitas dan kuantitas yang dicapai oleh seorang karyawan dalam melaksanakan tugasnya sesuai dengan tanggung jawab yang diberikan kepadanya.

Rumah Sakit Muhammadiyah Bandung merupakan rumah sakit Islam milik PW Muhammadiyah Jawa Barat yang berada di Bandung dan didirikan pada tanggal 18 November 1968. Rumah sakit ini memiliki motto "Rumah Sakit Muhammadiyah Bandung semangat melayani", serta visi "Menjadi Rumah Sakit Islam unggulan di Jawa Barat pada tahun 2018". Adapun misi yang dimiliki oleh Rumah Sakit Muhammadiyah Bandung ini yakni meningkatkan kualitas pelayanan berbasis IT, meningkatkan profesionalisme SDM yang Islami, meningkatkan kuantitas dan kualitas sarana dan prasarana pelayanan, meningkatkan kemitraan dengan pemangku kepentingan dan meningkatkan syiar dakwah Islam.

Quality of Nursing Work Life merupakan persepsi atau penilaian perawat mengenai seluruh dimensi yang mempengaruhi kualitas kehidupan kerjanya yang berhubungan dengan pengalaman dalam bekerja dalam rangka mencapai tujuan organisasi. Kualitas kehidupan kerja perawat (Quality of NursingWork Life) adalah sebuah konsep yang menggambarkan persepsi perawat terhadap pemenuhan kebutuhan melalui pengalaman kerja dalam organisasi, sehingga tujuan dari kualitas kehidupan kerja dapat selaras dengan fungsi manajemen untuk mengelola SDM yang unggul dan memiliki produktivitas kerja yang maksimal serta karyawan tersebut mendapat kepuasaan pribadi atas pemenuhan kebutuhannya (Brooks \& Anderson, 2005).

Menurut Brooks \& Andersoon (2005) terdapat empat dimensi yang mempengaruhi dan menjadi faktor-faktor dari Quality Of Nursing Work Life (QNWL) yaitu : (1) Dimensi Work Life- Home Life (pengalaman di tempat kerja dan di rumah), (2) Dimensi Work Design(komposisi pekerjaan), (3) Dimensi Work Context (pengaturan praktek) dan (4) Dimensi Work World (efek dari lingkungan sosial). Adapun faktor-faktor yang mempengaruhi QNWL menurut Hsu dan Kernohan (2006) yaitu : (a) sosial ekonomi, (b) demografi, (c) organisasi, (d) kerja, (e) hubungan manusia, \& (f) aktualisasi diri. Peneliti mengambil faktor demografi sebagai variabel yang akan diteliti. Dengan alasan dari semua faktor yang teridentifikasi 
mempengaruhi QNWL, hanya faktor demografi yang belum tercakup dalam teori yang menjadi landasan dasar penelti yaitu teori Brooks \& Andersoon (2005).

Menurut Gray dan Smeltzer (1990) terdapat tiga keuntungan yang dapat diperoleh dari penerapan kualitas kehidupan kerja. Pertama, keuntungan yang langsung diperoleh adalah meningkatkan komitmen terhadap organisasi diantara karyawan, kedua meningkatkan produktivitas/kinerja karyawan. Ketiga, berkaitan dengan dua keuntungan sebelumnya, adalah meningkatkan efektivitas organisasi (misalnya, profitabilitas, pencapaian tujuan perusahaan atau organisasi). Hal ini di perkuat oleh teori menurut Greenberg dan Baron (2000) yang menyatakan bahwa keuntungan dari QWL yaitu meningkatkan kepuasan kerja dan komitmen terhadap organisasi. Selain itu Riggio dalam Aryansah dan Kusumaputri (2013) mengemukakan bila QWL pada SDM baik, maka akan menimbulkan dampak positif bagi perusahaan, seperti menurunkan tingkat absensteeism (kemangkiran) dan turnover (perputaran SDM).

Berdasarkan hasil penelitian yang telah dilakukan dapat disimpulkan bahwa komitmen dan kinerja SDM meningkat dengan adanya program Quality of Work Life (QWL) yang diberikan oleh pihak organisasi (Fields \& Thacker, 1992; Sari, 2014; Melia, 2011; Nurhayati, 2014; Chrisienty, 2015; Zin, 2004; Ojedokun.,et al, 2015;Huang\& Lei, 2007).

Hasil penelitian Almalki, Fitzgerald \& Clark (2012) pada perawat puskesmas di Saudi Arabia dengan menggunakan kuesioner kualitas kehidupan kerja menurut teori Brooks menunjukkan bahwa responden tidak puas dengan kehidupan kerja mereka. Faktor-faktor yang paling besar mempengaruhi adalah jam kerja yang tidak cocok, kurangnya fasilitas untuk perawat, ketidakmampuan untuk menyeimbangkan pekerjaan dengan kebutuhan keluarga, ketidakcukupan waktu liburan untuk perawat dan keluarga mereka, staf miskin, manajemen dan praktik pengawasan, kurangnya kesempatan pengembangan profesional, dan bekerja lingkungan yang tidak pantas dalam hal tingkat keamanan, perlengkapan perawatan pasien dan peralatan, dan fasilitas rekreasi (break-area). Faktor penting lainnya termasuk pandangan masyarakat kepada keperawatan dan gaji yang tidak memadai. Faktor yang positif, perawat puas dengan rekan kerja, puas menjadi perawat dan memiliki rasa memiliki di tempat kerja mereka. Tidak ada perbedaan yang signifikan yang ditemukan sesuai dengan tingkat pendidikan perawat Puskesmas.

Hasil penelitian Cross-Sectional menurut Moradi, Maghaminejad \& Azizi (2014) dengan menggunakan kuesioner kualitas kehidupan kerja menurut teori Walton menunjukkan bahwa $60 \%(\mathrm{n}=92)$ perawat kualitas kehidupan kerja moderat sedangkan $37,1 \%(\mathrm{n}=56)$ kualitas kehidupan kerja kurang dan $2 \%(n=3)$ kualitas kehidupan kerja baik. Perawat dengan gelar asosiasi melaporkan kualitas hidup yang lebih baik bekerja daripada yang lain. Ada hubungan yang signifikan yang ditemukan antara variabel seperti tingkat pendidikan, pengalaman kerja, dan jenis rumah sakit dengan kualitas kehidupan kerja perawat $(\mathrm{P}$ $<0,05$ ). Tidak ada perbedaan signifikan antara kualitas kehidupan kerja perawat dengan status pekerjaan ( $\mathrm{P}=0,061)$, gaji $(\mathrm{P}=0,052)$, usia, jenis kelamin dan status pernikahan $(\mathrm{P}>0,05)$.

Berdasarkan hasil literatur review Yadav (2014) bahwa terdapat lebih dari 40 literatur didapatkan 25 literatur yang memenuhi kriteria. Hasil menunjukkan bahwa ada hubungan positif antara kualitas pekerjaan dan kehidupan karyawan. Berdasarkan hasil literatur review Phan \& Vo (2016) sebanyak 56 jurnal penelitian QWL yang di akses melalui PubMed, Science Direct, dan Cochrane Library databases sampai February 2015 pada negara Asia, Amerika, dan Eropa. Didapatkan 16 jurnal yang memenuhi kriteria, penelitian berfokus pada QWL perawat yang melibatkan lebih dari 200 peserta $(n=9$; $52,9 \%$ ) dalam penelitian. Didapatkan hasil 
bahwa faktor-faktor yang mempengaruhi QWL adalah kepuasan kerja, homework interface, kondisi kerja, kompensasi, hubungan manusia, hubungan manajemenpersonil.

Berdasarkan hasil studi pendahuluan terhadap kepala bidang keperawatan (KABID Keperawatan) terkait kinerja perawat yang merupakan bagian dari QNWL pada dimensi Work Design (komposisi pekerjaan) didapatkan data bahwa kinerja perawat dalam penerapan Asuhan Keperawatan pada tahun 2015-2016 masih belum maksimal. Data hasil pelaksanaan evaluasi penerapan Standar Asuhan Keperawatan tahun 2015 adalah $69,88 \%$, belum mencapai target yang di tetapkan $80 \%$, dengan angka terendah pada poin evaluasi keperawatan sebesar 56,46\%. Selain itu, data hasil observasi kegiatan Asuhan Keperawatan tahun 2015 adalah $86,36 \%$, belum mencapai target yang di tetapkan yaitu $95 \%$. Sedangkan data Bulan Januari s.d Agustus 2016, menunjukkan bahwa pelaksanaan evaluasi penerapan Standar Asuhan Keperawatan adalah $87,84 \%$, belum mencapai target yang di tetapkan 90\%. Hasil observasi kegiatan Asuhan Keperawatan Januari s.d Agustus 2016 adalah 91,87\%, belum mencapai target yang di tetapkan $95 \%$.

Hasil studi pendahuluan di RS Muhammadiyah Bandung, yang dilakukan kepada kepala ruangan dan perawat di RS Muhammadiyah Bandung pada bulan November 2016 terkait Quality of Nursing Work Life (QNWL) pada dimensi Work Design(komposisi pekerjaan) menunjukkan bahwa para perawat di Rumah Sakit Muhammadiyah mengatakan bahwa mereka masih banyak melakukan pekerjaan nonkeperawatan. Seperti mengerjakan administrasi yang nantinya akan diserahkan kepada bagian keuangan untuk dilakukan pembayaran, membuat laporan untuk laboratorium, mengurus asuransi pasien dan juga melakukan instalasi peralatan medis. Perawat merasa bahwa bagian administrasi itu seharusnya dilakukan oleh bagian lain, karena tugasnya sebagai perawat ialah fokus untuk menangani pasien. Pada dimensi Work LifeHome Life ( pengalaman di tempat kerja dan di rumah) menunjukkan bahwa perawat mengeluhkan lelah setelah bekerja di rumah sakit dan sepulang kerumah perawat juga sibuk memperhatian kebutuhan anak dan keluarganya sehingga waktu istirahat berkurang. Perawat juga tidak memiliki waktu liburan yang panjang dengan keluarga hal ini sering menimbulkan konflik individu antara pengalaman hidup perawat di tempat bekerjanya dengan kehidupan di rumahnya.

Hasil studi pendahuluan pada dimensi Work World (efek dari lingkungan sosial) menunjukkan bahwa perawat di RS Muhammadiyah masih mengeluhkan kompensasi yang dirasa belum adil karena belum disesuaikan dengan kinerja perawat. Perawat di RS Muhammadiyah Bandung selain mendapatkan gaji pokok, juga mendapatkan insentif kinerja, tunjangan fungsional, tunjangan anak dan uang pesangon. Perawat di sana telah mendapatkan asuransi kesehatan yaitu BPJS kesehatan. Selain itu, perawat mengeluhkan belum terdapat kebijakan tunjangan pensiun di RS Muhammadiyah Bandung.

Hasil studi pendahuluan pada dimensi Work Context (pengaturan praktek) menunjukkan bahwa perawat di RS Muhammadiyah mengeluhkan penerapan jenjang karir perawat belum terlaksana dengan maksimal yaitu masih pada tahap pelaksanaan mapping jenjang karir. hanya menggunakan kriteria lama kerja di RSMB dan tingkat pendidikan saja. Proses mapping masih belum dilakukan dengan kriteria kompetensi (uji kompetensi), hanya menggunakan kriteria lama kerja di RSMB dan tingkat pendidikan saja. Mapping jenjang karir tersebut juga belum dihubungkan dengan kompensasi yang didapatkan berupa tunjangan fungsional. Tunjangan fungsional diberikan sama rata sesuai dengan pendidikan perawat

\section{METODE}


Penelitian deskriptif cross- sectional survey ini, melibatkan 94 perawat yang diambil dengan cara kuantitatif. Data dikumpulkan dengan kuesioner, dan dianalisis menggunakan uji non-parametrik Mann Whitney. Metode pengambilan sampel untuk penelitian ini dilakukan menggunakan teknik sampling yaitu Stratified Random Sampling. Penelitian ini dilakukan pada akhir bulan Januari 2017 di Rumah Sakit Muhammadiyah Bandung.

Pengumpulan data variabel independen/bebas dan dependen/terikat menggunakan kuesioner. Format data demografi responden terdiri dari pertanyaan nomor 1, umur; nomor 2, jenis kelamin; nomor 3, pendidikan terakhir; nomor 4, status pernikahan; nomor 5, lama kerja sebagai perawat; nomor 6, lama kerja sebagai perawat di RS Muhammadiyah Bandung. Pertanyaan tersebut diisi dengan cara mengisi jawaban pada lembar biodata responden.

Kuesioner digunakan untuk mengukur variabel QNWL. Kuesioner diambil dari Quality Of Nursing Work Life (QNWL) menurut Brooks \& Andersoon (2005). yang sudah dilakukan uji validitas \& reabilitas dengan alfa cronbach $=0,938$. Jumlah pertanyaan dalam kuesioner QNWL adalah 42 pertanyaan dengan 4 pilihan jawaban, sehingga total nilai minimum dan maksimum untuk kualitas kehidupan kerja dari perawat adalah $42-168$.

Hasil keluaran tersebut dibandingkan dengan nilai standar dari $Q N W L$ skala Brook yaitu nilai tengah dan rentang nilai $Q N W L$ skala Brook, sehingga dapat dianalisis makna hasil temuan $Q N W L$ dalam penelitian ini. Jika hasil keluaran lebih tinggi dari rentang nilai dan nilai tengah $Q N W L$ skala Brook maka QNWL dikatakan baik, demikian pula sebaliknya (Brook \&Anderson, 2005). Nilai tengah dan rentang nilai skala Brook disajikan dalam tabel 1 berikut:

Tabel 1. Penilaian $Q N W L$ skala Brook

\begin{tabular}{lcc}
\hline $\begin{array}{c}\text { Variabel/ } \\
\text { Sub variabel }\end{array}$ & $\begin{array}{c}\text { Rentang } \\
\text { Nilai } \\
\text { Skala Brook }\end{array}$ & $\begin{array}{c}\text { Nilai } \\
\text { Tengah } \\
\text { Skala } \\
\text { Brook }\end{array}$ \\
\hline $\begin{array}{l}\text { QNWL } \\
\text { Keseluruhan }\end{array}$ & $42-168$ & 105 \\
\hline $\begin{array}{l}\text { Dimensi Work } \\
\text { life-Home Life }\end{array}$ & $7-28$ & 17.5 \\
\hline $\begin{array}{l}\text { Dimensi Work } \\
\text { Design }\end{array}$ & $10-40$ & 25 \\
\hline $\begin{array}{l}\text { Dimensi Work } \\
\text { Context }\end{array}$ & $20-80$ & 50 \\
\hline $\begin{array}{l}\text { Dimensi Work } \\
\text { World }\end{array}$ & $5-20$ & 12.5 \\
\hline
\end{tabular}

HASIL

Gambaran Demografi Perawat RS Muhammadiyah Bandung

Tabel 2. Distribusi Frekuensi Demografi Responden $(\mathrm{N}=94)$

\begin{tabular}{lcc}
\hline \multicolumn{1}{c}{ Variabel } & $\begin{array}{c}\text { Frekuensi/ } \\
\text { Jumlah }\end{array}$ & $\begin{array}{c}\text { Persentase } \\
(\%)\end{array}$ \\
\hline Jenis Kelamin & & \\
\hline Laki-laki & 18 & 19.1 \\
\hline Perempuan & 76 & 80.9 \\
\hline Umur & \\
\hline$<30.4$ tahun & 50.0 \\
\hline$\geq 30.5$ tahun & 50.0 \\
\hline Status Pernikahan & 47 & 19.1 \\
\hline Belum Menikah & 18 & 80.9 \\
\hline Menikah & 76 & 78.7 \\
\hline Tingkat Pendidikan & & 21.3 \\
\hline DII Keperawatan & 74 & \\
\hline S1 Keperawatan & 20 & 47.9 \\
\hline Lama Kerja sebagai Perawat & 52.1 \\
\hline$\leq 7$ tahun & 45 & 42.6 \\
\hline$\geq 8$ tahun & 49 & 57.4 \\
\hline Lama Kerja di RS Muhammadiyah & Bandung \\
\hline$\leq 6$ tahun & 40 & 54 \\
\hline$\geq 7$ tahun & & \\
\hline
\end{tabular}

Gambaran Quality of Nursing Work Life (QNWL) Perawat di RS Muhammadiyah Bandung

Berdasarkan tabel, dapat dilihat bahwa rentang nilai dan mean $Q N W L$ perawat di RSMB (rentang nilai: 69-128, mean: 111.53) lebih tinggi dari rentang nilai dan nilai tengah 
QNWL skala Brook (rentang nilai: 42-168, nilai tengah: 105).

Tabel 3. Gambaran Quality of Nursing Work Life $(Q N W L)$ Berdasarkan 4 Dimensi

\begin{tabular}{lccc}
\hline $\begin{array}{c}\text { Variabel/ } \\
\text { Sub } \\
\text { variabel }\end{array}$ & $\begin{array}{c}\text { Rentang } \\
\text { Nilai }\end{array}$ & $\begin{array}{c}\text { Nilai } \\
\text { Mean }\end{array}$ & $\begin{array}{c}\text { Standar } \\
\text { Deviasi }\end{array}$ \\
\hline $\begin{array}{l}\text { QNWL } \\
\text { Keseluruhan }\end{array}$ & $69-128$ & 111.53 & 10.807 \\
\hline $\begin{array}{l}\text { Dimensi } \\
\text { work life- } \\
\text { home life }\end{array}$ & $11-26$ & 18.40 & 2.849 \\
\hline $\begin{array}{l}\text { Dimensi } \\
\text { work design }\end{array}$ & $19-32$ & 26.48 & 2.774 \\
\hline $\begin{array}{l}\text { Dimensi } \\
\text { work context }\end{array}$ & $31-65$ & 53.95 & 5.881 \\
\hline $\begin{array}{l}\text { Dimensi } \\
\text { work world }\end{array}$ & $7-15$ & 12.70 & 1.565 \\
\hline
\end{tabular}

Hal ini bermakna bahwa $Q N W L$ perawat di RSMB berada dalam kategori baik. Demikian pula dengan rentang nilai dan mean semua Dimensi $Q N W L$ perawat di RSMB (work life/ home life $=$ rentang nilai: 11-26, mean: 18.40 ; work design $=$ rentang nilai: 19 32, mean: 26.48; work context $=$ rentang nilai:
31-65, mean:53.95; dan work world= rentang nilai: 7-15, mean:12.70) berada lebih tinggi dari rentang nilai dan nilai tengah $Q N W L$ skala Brook (work life/ home life $=$ rentang nilai: 728, mean: 17.5; work design $=$ rentang nilai: 10-40, mean: 25 ; work context $=$ rentang nilai: 20-80, mean:50; dan work world $=$ rentang nilai: 5-20, mean:12.5). Hal ini bermakna bahwa semua dimensi $Q N W L$ perawat di RSMB berada dalam kategori baik.

\section{Faktor-Faktor Demografi yang Mempengaruhi Quality of Nursing Work Life (QNWL) Perawat di RS Muhammadiyah Bandung}

Dari tabel 4, kita dapat melihat bahwa terdapat pengaruh yang signifikan faktor: jenis kelamin $(p=0.04, \alpha=0.05)$, umur responden $(p=0.006, \alpha=0.05)$ dan lama bekerja sebagai perawat $(\mathrm{p}=0.009$, $\alpha=0.05)$ terhadap Quality of Nursing Work Life (QNWL) perawat di RS Muhammadiyah Bandung. Namun, kita juga dapat melihat bahwa tidak terdapat

Tabel 4 Faktor-Faktor Demografi yang Mempengaruhi Quality of Nursing Work Life (QNWL) Perawat

\begin{tabular}{|c|c|c|c|c|}
\hline Variabel & Mean $Q N W L$ & $\begin{array}{c}\text { SD } \\
Q N W L\end{array}$ & $\mathrm{Z}$ value & P value \\
\hline \multicolumn{5}{|l|}{ Jenis Kelamin } \\
\hline Laki-laki & 106.33 & 2.888 & \multirow[t]{2}{*}{-2.054} & \multirow[t]{2}{*}{0.040} \\
\hline Perempuan & 112.76 & 1.163 & & \\
\hline \multicolumn{5}{|l|}{ Umur } \\
\hline$<30.4$ tahun & 108.21 & 12.387 & \multirow[t]{2}{*}{-2.744} & \multirow[t]{2}{*}{0.006} \\
\hline$\geq 30.5$ tahun & 114.85 & 7.757 & & \\
\hline \multicolumn{5}{|l|}{ Status Pernikahan } \\
\hline Belum Menikah & 108.28 & 2.403 & \multirow[t]{2}{*}{-1.804} & \multirow[t]{2}{*}{0.71} \\
\hline Menikah & 112.30 & 1.247 & & \\
\hline \multicolumn{5}{|l|}{ Tingkat pendidikan } \\
\hline DII Keperawatan & 113.03 & 1.011 & \multirow[t]{2}{*}{-1.790} & \multirow[t]{2}{*}{0.074} \\
\hline S1 Keperawatan/Ners & 106.00 & 3.465 & & \\
\hline \multicolumn{5}{|c|}{ Lama Bekerja sebagai Perawat } \\
\hline$\leq 7$ tahun & 108.20 & 12.416 & \multirow[t]{2}{*}{-2.618} & \multirow[t]{2}{*}{0.009} \\
\hline$\geq 8$ tahun & 114.59 & 8.062 & & \\
\hline \multicolumn{5}{|c|}{ Lama Bekerja sebagai Perawat di RS Muhammadiyah Bandung } \\
\hline$\leq 6$ tahun & 109.50 & 12.174 & \multirow[t]{2}{*}{-1.363} & \multirow[t]{2}{*}{0.173} \\
\hline$\geq 7$ tahun & 113.04 & 9.511 & & \\
\hline
\end{tabular}


pengaruh yang signifikan faktor: status pernikahan $(p=071, \alpha=0.05)$, tingkat pendidikan $(p=0.074, \alpha=0.05)$ dan lama bekerja sebagai perawat di rumah sakit Muhammadiyah $\quad(\mathrm{P}=0.173, \quad \alpha=0.05)$ terhadap $Q N W L$ perawat di RSMB.

\section{PEMBAHASAN}

\section{Gambaran Quality of Nursing Work Life (QNWL) Perawat di RS Muhammadiyah Bandung}

Hasil penelitian ini menunjukkan bahwa QNWL perawat secara keselurahan dan semua dimensi (work life-home life, work context, work design, work world) QNWL perawat di RSMB berada dalam kategori baik. Hal ini sejalan dengan penelitian Khoerullah (2015) di RSUD Berkah Pandeglang yang menyimpulkan bahwa gambaran $Q N W L$ secara keseluruhan, dimensi work life-home life dan dimensi work context di RSUD Berkah Pandeglang berada pada kategori baik. Namun demikian gambaran dimensi work design dan work world di RSUD Berkah pandeglang berada pada kategori buruk.

Hasil penelitian ini sejalan dengan hasil penelitian di USA dan Iran, yang menunjukkan bahwa perawat secara keseluruhan cukup puas dengan kualitas kehidupan kerja mereka (Brooks et al., 2005; Nasl \& Dargahi 2006; Dargahi et al., 2007). Namun beberapa penelitian lainnya menyimpulkan bahwa perawat memiliki $Q N W L$ yang moderat bahkan buruk (Moradi et al., 2014; Heidari et al; 2010; Nayeri et al., 2011; Suresh, 2013). Penelitian yang menyimpulkan QNWL buruk, diantaranya adalah penelitian Dargahi et al. (2012) yang menyatakan bahwa perawat kesehatan masyarakat di Iran tidak puas dengan $Q N W L$ di tempat kerjanya. Selain itu, Sharhraky et al. (2011) juga menyatakan bahwa perawat di Rumah Sakit Isfahan Saudi Arabia memiliki $Q N W L$ yang buruk.

Walaupun $Q N W L$ perawat di RSMB sudah tergolong baik, masih perlu ada beberapa perbaikan sehingga $Q N W L$ menjadi lebih baik lagi sehingga kualitas pelayanan keperawatan-pun akan lebih baik lagi. Hal ini sesuai dengan teori beberapa ahli yang menyatakan bahwa $Q N W L$ dapat digunakan untuk meningkatkan kualitas keperawatan dan efektivitas organisasi (Hanlon \& Gladstein, 1984; Clarke \& Brooks, 2010; Schalk et al., 2010). Selain itu, Gray dan Smeltze (1990) menyatakan terdapat tiga keuntungan yang dapat diperoleh dari penerapan kualitas kehidupan kerja, yakni dapat meningkatkan komitmen pegawai, produktivitas, dan efektivitas organisasi. Kurangnya komitmen pegawai dalam organisasi dapat menyebabkan berkurangnya efektivitas organisasi (Walton, 1974). Selain itu, rendah nya kualitas kehidupan kerja pegawai juga berdampak pada bertambahnya ketidakhadiran pegawai dan banyaknya pegawai yang memundurkan diri (Lazarova, 2004). Oleh karena itu, meningkatkan $Q N W L$ merupakan langkah yang lebih praktikal dan merupakan pendekatan jangka panjang untuk meningkatkan kualitas organisasi, menarik minat dan mempertahankan pekerja yang harus dipertimbangkan oleh manajer.

\section{Faktor-Faktor Demografi yang Mempengaruhi Quality of Nursing Work Life (QNWL) Perawat di RS Muhammadiyah Bandung}

\section{Pengaruh Faktor Jenis Kelamin}

Hasil penelitian ini menunjukkan bahwa terdapat pengaruh yang signifikan faktor jenis kelamin $(\mathrm{p}=0.04)$ terhadap Quality of Nursing Work Life (QNWL) perawat di RS Muhammadiyah Bandung. Hal ini sejalan dengan seluruh penelitian yang peneliti temukan. Penelitian-penelitian tersebut juga menyimpulkan bahwa terdapat pengaruh yang signifikan faktor jenis kelamin terhadap QNWL perawat (Sochalski, 2002; Heydari et al, 2011; Sharhraky et al. 2011; Moradi, et al., 2014; Nayeri et al, 2011; Darghahi et al, 2012; Heidari, 2012). Selain itu, penelitian ini 
menunjukkan bahwa perawat laki-laki memiliki mean $Q N W L$ yang lebih rendah dibandingkan dengan perawat perempuan. Hal ini sejalan dengan penelitian Sochalski (2002) dan Heidari et al (2012) menyatakan bahwa perawat laki-laki memiliki $Q N W L$ yang lebih rendah dibandingkan dengan perawat perempuan. Namun, hal ini tidak sejalan dengan penelitian Sharhraky et al. (2011) yang menyatakan bahwa perawat laki-laki memiliki QNWL lebih tinggi. Menurut penelitian Khaghanizadeh et al. (2008), rendahnya nilai QNWL perawat laki-laki bisa disebabkan karena perawat laki-laki yang biasanya terlibat pada pekerjaan perawat yang lebih berat. Perlu penelitian lebih lanjut untuk mengetahui penyebab perawat laki-laki di RSMB memiliki QNWL lebih rendah dibandingkan perawat perempuan, untuk selanjutnya dilakukan upaya perbaikan $Q N W L$ perawat laki-laki di RSMB.

\section{Pengaruh Faktor Umur dan Lama Bekerja sebagai Perawat}

Hasil penelitian ini menunjukkan bahwa terdapat pengaruh yang signifikan faktor umur $(\mathrm{p}=0.006)$ dan lama bekerja sebagai perawat $(\mathrm{p}=0.009)$ terhadap Quality of Nursing Work Life (QNWL) perawat di RS Muhammadiyah Bandung. Perawat berusia $\geq 30.5$ tahun memiliki mean $Q N W L$ yang lebih tinggi dibandingkan dengan perawat berusia $\leq 30.4$ tahun. Selain itu, perawat dengan pengalaman $\geq 8$ tahun memiliki mean $Q N W L$ yang lebih tinggi dibandingkan dengan perawat dengan pengalaman $\leq 7$ tahun. Hal ini sejalan dengan semua penelitian-penelitian tentang $Q N W L$ yang peneliti temukan. Penelitian-penelitian tersebut menunjukkan bahwa perawat yang lebih tua dan memiliki pengalaman lebih banyak, memiliki $Q N W L$ yang lebih tinggi dibandingkan dengan perawat yang lebih muda dan kurang berpengalaman (Sochalski, 2002; Shields \& Ward, 2001; Bjork et al., 2007). Hal ini berkaitan dengan kemampuan perawat berumur tua yang lebih baik dalam membuat penyesuaian dengan lingkungan bekerja, dibandingkan dengan perawat yang lebih muda (Shah et al., 2004). Selain itu, pegawai yang lebih muda cenderung kurang puas karena berpengharapan tinggi dan kurang penyesuaian (Davis \& Newstroom, 2004). Dalam kata lain, lamanya pengalaman memungkinkan menambahnya wawasan dan kompetensi perawat, sama halnya dengan pemahaman yang terkait dengan pekerjaan. Oleh karena itu, salah satu upaya yang perlu dilaksanakan untuk meningkatkan $Q N W L$ perawat berusia muda padalah kegiatan sharing pengalaman dari perawat yang lebih senior kepada perawat junior.

\section{Pengaruh Faktor Status Marital, Faktor Tingkat Pendidikan, Faktor Lama Bekerja sebagai Perawat di RSMB}

Hasil penelitian ini menunjukkan bahwa tidak terdapat pengaruh yang signifikan status marital ( $\mathrm{p}=0.71)$ terhadap Quality of Nursing Work Life (QNWL) perawat di RS Muhammadiyah Bandung. Hal ini sejalan dengan penelitian lain yang menunjukkan tidak terdapat hubungan signifikan antara status pernikahan dengan $Q N W L$ (Moradi et al. 2014; Nayeri et al.,2011; Dargahi et al., 2012).

Hasil penelitian ini menunjukkan bahwa tidak terdapat pengaruh yang signifikan tingkat pendidikan $(\mathrm{p}=0.074)$ terhadap Quality of Nursing Work Life (QNWL) perawat di RS Muhammadiyah Bandung. Hal ini sejalan dengan penelitian Dargahi et al. (2012) dan Sahrakivahed et al. (2011) yang menyatakan tidak terdapat hubungan signifikan antara tingkat pendidikan dengan $Q N W L$ perawat. Namun hal ini tidak sejalan dengan penelitian Moradi et al. (2014) yang menyatakan bahwa terdapat hubungan signifikan antara tingkat pendidikan dan $Q N W L$.

\section{SIMPULAN}

Hasil penelitian ini menunjukkan bahwa sebagian besar perawat di Rumah Sakit Muhammadiyah Bandung adalah perempuan $(\mathrm{n}=76,80.9 \%)$, menikah $(\mathrm{n}=76,80.9 \%)$, berpendidikan D III Keperawatan $(\mathrm{n}=74$, 
78.7\%), 52.1\% memiliki pengalaman sebagai perawat $\geq 8$ tahun dan $57 \%$ memiliki pengalaman kerja $\geq 7$ tahun di RSMB. Hasil penelitian ini menunjukkan bahwa perawat di RSMB memiliki nilai QNWL secara keseluruhan dan dimensi-dimensi QNWL yang berada dalam kategori baik. Hasil penelitian ini juga menunjukkan bahwa tiga faktor demografi berpengaruh signifikan terhadap QNWL perawat, yaitu: faktor jenis kelamin $(p=0,04)$, umur $(p=0,006)$, dam lama bekerja di rumah sakit $(0,009)$. Sedangkan, dari segi status pernikahan $(\mathrm{p}=0,71)$, tingkat pendidikan $(p=0,074)$ dan lama bekerja di RSMB $(p=0,173)$ tidak berpengaruh signifikan terhadap QNWL perawat.

\section{DAFTAR PUSTAKA}

Almalki, M.,et all (2012). Quality of work life and turnover intention in primary healthcare organisations: A crosssectional study of registered nurses in Saudi Arabia. Queensland University of Technology: Faculty of Health. $\mathrm{PhD}$ Thesis.

Almalki, M., Fitzgerald, G., \& Clark, M. (2012). Quality of work life among primary health care nurses in the Jazan region, Saudi Arabia: a cross-sectional study. Human Resources for Health, 10(10), 30 .

Aryansah, I., Kusumaputri, E.S. (2013). Iklim Organisasi dan Kualitas Kehidupan Kerja Karyawan. Humanitas (Jurnal Psikologi Indonesia), 10(1): 75-86.

Brooks, B. A., Anderson, M. A. (2005). Defining Quality of Nursing Work Life. Nursing Economics, 23(6), 279,319-326.

Bjork, I.T., Samdal, G.B., Hansen,B.S., Torstad,S., Hamiltom,G.A. (2007). Job satisfaction in a Norwegian population of nurses: A questionnaire survey. International Journal of Nursing Studies, 44 (5), 747-757.

Chrisienty,Wenda. (2015). Pengaruh Quality Of Work Life Terhadap Komitmen
Organisasional Karyawan Di CV Sinar Plasind. AGORA, 3(2), 483-490.

Clarke, P., Brooks,B. (2010). Quality of nursing worklife: Conceptual vlarity for the future. Nursing Science Quarterly, 23 (4), 301-305.

Dargahi, H., Gharib, M., Goudarzi, M. (2007). Assessment of the nurses' quality of work life in hospitals affliated to Teheran Medical Sciences University. HAYAT: The $J$ Tehran FacNurs \& Midwifery, 13, 13-21.

Dargahi, H., Changizi, V., Jazayeri, G.E. (2012). Radiology employee's quality of work life. Acta Medica Iranica Journal, 50 (4), 250-230.

Davis, K., Newstroom. (2004). Perilaku dalam organisasi. Erlangga: Jakarta.

Fields, Mitchel W., and James W. Thacker. (1992).Influence of Quality of Work Life on Company and Union Commitment. Academy of Management journal, 35(2), 439-450

Gray and Smeltzer. (1990). An Analisis of Quality of Work Life (QWL) and career related variable. American Journal of Applied Sciences, 3 (12), 2151-2159.

Greenberg, Jerald dan Baron, Robert A. (2000). Perilaku Organisasi. Jakarta : Prentice Hall

Hanlon, M., Gladstein, D. (1984). Improving the quality of work life in hospitals: A case study. Hospital and Helath Services Administration, 29 (5), 94107.

Heidari, A., Askary, P., \& Saedi, S. (2012). Relationship between quality of work life, organizational health and commitment with job satisfaction. Life Science Journal, 9(3).

Heidari, A., Enayati, A., Hedayatio, A. (2010). Quality of work life and job satisfaction among the nurses of Tehran university of medical sciennces. Dena Journal, 5 (4), 28-37 
Hsu, M.Y., Kernohan, G. (2006) .Dimensions of hospital nurses' quality of workinglife. J AdvNurs, 54(1):120131.

Huang, T., Lawler, J., \& Lei, C. (2007). The Effects Of quality of Work Life On Commitment And Turnover Intention. Social Behavior and Personality, 35(6), 735-750. Retrieved from http://search.proquest.com/docview/2 09905760 accountid $=25704$

Ilyas. (2002). Manajemen Sumber Daya Manusia. FKM UI : Depok.

International Council of Nurses (1965). Position statements. Geneva: ICN

Khaghanizadeh, M., Ebadi, A., Cirati, N.M., Rahmani, M. (2008). The study of relationship between job stress and quality of work life of nurses in military hospitals. Journal of Military Medicine, 10(3), 175-184.

Khoerullah, Heru. (2015). Hubungan Quality Of Work Life Perawat Dengan Kepuasan Pasien Di RSUD Berkah Pandeglang. Tesis. Fakultas Keperawatan Universitas Padjajaran: Bandung.

Lazarova, M. B. (2004). The role of organizational career development programs, work llife balance programs, and commitment to career and personal life for retention of professional employees (Order No. 3117615). Available from ProQuest Dissertations \& Theses Global: The Humanities and Social Sciences Collection. (305154239). Retrieved from

http://search.proquest.com/docview/3 05154239? accountid $=25704$.

Mangkunegara. (2003). Perencanaan dan Pengembangan SumberDaya Manusia.Bandung: Refika Aditama.

Melia, I. (n.d.). Analisis Komitmen Organisasi Melalui Faktor Quality Of Work Life ( Studi Kasus Fakultas Ekonomi dan
Manajemen Institut Pertanian Bogor), II(3), 79-88.

Moradi, T., Maghaminejad, F., \& Azizi-fini, I. (2014). Quality of working life of nurses and its related factors. Nurse Midwifery Study, 3(2).

Nasl Saraji, G., Dargahi, H. (2006). Study of quality of work life (QWL). Iranian Journal of Publich Health, 35 (4), 814.

Nayeri,N.D., Salehi, T., Noghabi, A..A. (2011). Quality of work life and productivity among Iranian nurses. Contemporary Nurse, 39 (1), 10-18

Nurhayati, Teti. (2014). Pengaruh Kualias Kehidupan Kerja Terhadap Komitmen Organisasi Pada Yayasan Kesejahteraan Karyawan Bank Indonesia (YKKBI) Skripsi pada Fakultas Ekonomi dan Manajemen. Institute Pertanian Bogor

Ojedokun, O., Idemudia, E. S., \& Desouza, M. (2015). Perceived external prestige as a mediator between quality of work life and organisational commitment of public sector employees in ghana. $S A$ Journal of Industrial Psychology, 41(1), 1-10. Retrieved from http://search.proquest.com/docview/1 692699054 ? accountid $=25704$

Phan, G., \& Vo, T. (2016). A Literature Review on Quality of Working Life: A Case of Healthcare Workers. Journal of Applied Pharmaceutical Science, $6(7)$,

193-200. https://doi.org/10.7324/JAPS.2016.60 729

Potter \& Perry (2005) Buku Ajar Fundamental Keperawatan : Konsep, Proses \& Praktek. Edisi 4. Vol 1. Jakarta : EGC

PPNI Indonesia. (2005). Standar Kompetensi Perawat Indonesia. dari PPNI Indonesia website: http://www.innappni.or.id

Sari, Nurmala. (2014). Analisis Pengaruh Kualitas Kehidupan Kerja Terhadap Komitmen Organisasi Perawat 
Pelaksana Di Rumah sakit Universitas

Hasanuddin. Tesis Ilmu kesehatan masyarakat Universitas Hasanuddin.Makasar

Schalk, D., Bijil, M., Halfens, R., Hollands, L., Cumming, G. (2010). Interventions aimed at improving the nursing work environment: A systemic review. Implementation Science, 5 (34).

Shah, M.A., Al-Enezi, N., Chowdhury, R.I., Al Otabi, M. (2004). Determinants of job satisfaction among nurses in Kuwait. Australian Journal of Advanced Nursing. 21 (4), 10-16.

Sharhraky, V.A., Mardani, H.M., Asadi, B.E., Heidar, M.,Hamedi, S.S. (2011). Assessment of the items of SCL90 tes with quality of work life among Amiralmomenin Hospital personnel of Zabol city. Scientific Journal of Hamadan University of Medical Sciences, 18 (2), 50-55.

Shields, M.A., Ward,M. (2001). Improving nurse retention in the National Health Service in England: The impact of job satisfaction on intentions to quit. Journal of Health Economics, 20 (5), 677-701.

Sochalski, J. (2002). Nursing shortage redux: Turning the corner on an enduring problem. Health Affairs, 21 (5), 177164
Soekidjan. (2009). Manjaemen Sumber Daya Manusia. Jakarta: BumiAksar

Soeroso, 2003.Manajemen Sumber Daya Manusia di Rumah Sakit Jakarta.Jakarta:ECG.

Suresh, M. D. (2013). Quality of Nursing Work Life among nurses working in selected government and private hospitals in Thiruvananthapuram, (October), 1-87.

Swansburg, R. C. (2000). Pengantar Kepemimpinan dan Manajemen Keperawatan.Jakarta : $\quad$ EGC terjemahan

Yadav,Radha. (2014). Literature Review on Quality of Work Life and Their Dimensions. IOSR Journal Of Humanities And Social Science (IOSR-JHSS), 19(9), 71-80. https://doi.org/10.9790/083719957180

Walton, R. (1974).Quality of Work Life Activities: A research Agenda.American Psychological Assosiation, Inc. Journal Proffesional Psychology, 11(3)

Zin, M.R. (2004). Perception of professional engineers toward Quality of Work Life and organizational commitment. Gajah Mada International Journal of Bussiness. 06 : 323-324. 